\title{
Deus ex Machina? Religious texts, spiritual capital and inequalities: In continuation of a current debate (a response to colleague Farisani)
}

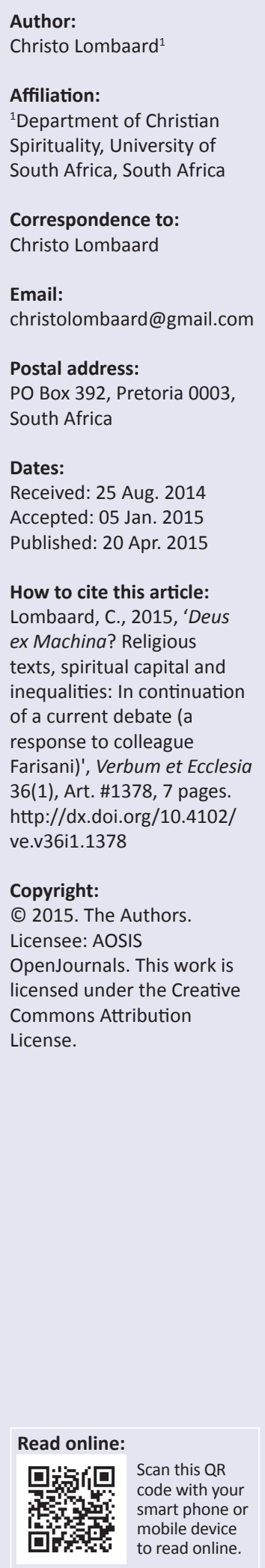

Often, theological debates stand in the tension between idealist and realist perspectives. This is true too of a discussion in which I have participated on the Africanisation or contextualisation or relevance of the Bible in (South) Africa. In this debate I have at times been cast as being opposed to such Africanisation or contextualisation or relevance. Such criticism is mistaken. I am, however, critical of too idealistic views on the ways in which Old Testament research can impact African problems. In an interdisciplinary manner, the sociological concept of spiritual capital proves useful in illustrating my view. With this, I hope to be understood correctly and, more importantly, to contribute to greater realism concerning the relationship between research and societal problems. In that way, the Africanisation or contextualisation or relevance of the Bible in (South) Africa can become a greater reality. This is of increased importance in the post-secular time frame in which we currently find ourselves, in which the role of religion in the public sphere is again finding greater acceptance rather than being side-lined. On all counts, thus, the plight of the marginalised may be better served. Such broader acceptance of religion also demands that Bible scholarship takes full cognisance of the societal processes through which such upliftment can occur in reality. Therefore, en route to publication, this contribution is presented for critical consideration in three intellectual fora:

- The Religious and Spiritual Capital session, XVIIIth International Sociological Association World Congress of Sociology (conference theme: 'Facing an unequal world'), Yokohama, Japan, 13-19 July 2014.

- The Old Testament Society of South Africa Annual Conference (conference theme: 'Studying the Old Testament in South Africa, from 1994 to 2014 and beyond'), University of Johannesburg, 03-05 September 2014.

- The Research Day of the Department of Biblical and Ancient Studies, University of South Africa, 25 September 2014, at which colleague E. Farisani's University of South Africa inaugural lecture of 03September 2013, 'Dispelling myths about African biblical hermeneutics: The role of current trends in African biblical hermeneutics in the post-apartheid South Africa' was re-presented as 'Current trends and patterns in African Biblical Hermeneutics in postapartheid South Africa: Myth or Fact?' for the purpose of critical discussion.

Intradisciplinary and/or interdisciplinary implications: The intersection of Theology and Sociology adds concrete avenues for furthering the cause of the Africanisation of Biblical Studies.

\section{Setting the picture}

I have recently been directed to Raphael's Vatican fresco Scuola di Atene (Figure 1), within which an assembly of classic Greek philosophers are depicted. Centrally placed are the two figures who have whispered along in practically every argument in Western(ised) societies over the past 24 centuries: Plato and Aristotle. Pointedly, Plato, the idealist, gestures upwards - there lies his essence (the book he bears is his, on the cosmos). Aristotle, the realist, gestures towards his surroundings - there lies his commitments (on his part, his book is on ethics; cf. Caputo 2006:1213). As teacher and student at odds, Plato and Aristotle signify the ever-present dichotomy in Christian Theology: ${ }^{1}$ between heaven and earth, ${ }^{2}$ soul and body, principle and practice, love for

\footnotetext{
1.In this presentation, academic disciplines are indicated by means of capitalisation.

2.The opposites are also thematically present in the well-known 'Lord's prayer', specifically in Matthew 6:10 (emphases added): $\dot{\varepsilon} \lambda \theta \dot{\varepsilon} \tau \omega \dot{\eta} \beta \alpha \sigma i \lambda \varepsilon \dot{\alpha} \alpha$ бov.

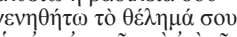

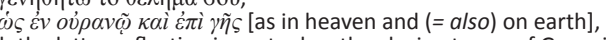

with the latter reflecting in metaphor the closing terms of Genesis 1:1:

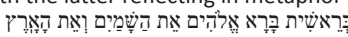




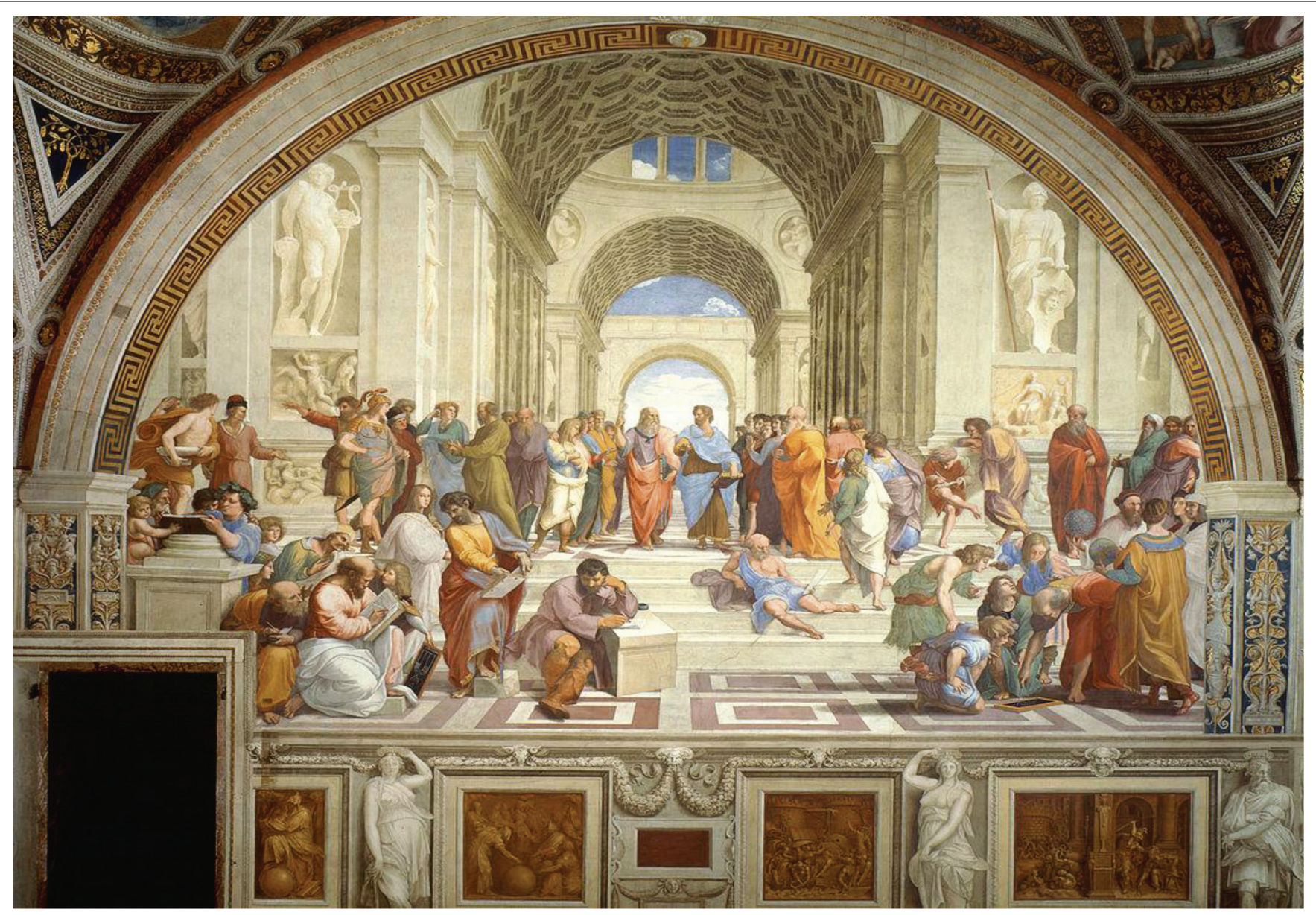

Source: Vatican fresco, c. 1510, http://mv.vatican.va/2_IT/pages/x-Schede/SDRs/SDRs_03_02_020.html

FIGURE 1: Raphael: Scuola di Atene.

God and/or love for humanity, ${ }^{3}$ the spiritual and the material, the possible and the actual - where does first emphasis fall? In the wake of millennia of the Platonic-Aristotelian dichotomy into which the early Christian religion was fully brought, ${ }^{4}$ all Western(ised) religious thought has been (un) balanced.

It is this tension, still, that lies at the heart of many recent theological discussions in South Africa (as elsewhere), in one of which I have been participating. However, given the passionsthe personal, political, social, theological and (perhaps not always fully aware) philosophical commitments - involved, the representations that have characterised this debate have not always been fair. The recent conceptual enlargements of the by now foundational sociological concept of social capital (cf. Gelderblom 2014) ${ }^{5}$ to extend also to religious or spiritual capital may prove helpful in illuminating this situation. This concept cluster may well provide an intellectual framework

3.This unresolved tension is present in the imagined Jesus words in Matthew 22:3739 too:

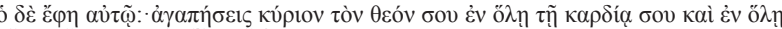

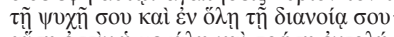

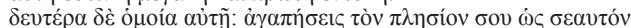

4.This is meant here as an analytical remark, rather than evaluative.

5.My thanks to colleagues Derik Gelderblom, Michael O'Sullivan and Hans van Rensburg, whose comments on social and religious capital during various stages of the writing of this contribution have proven helpful. for - the intention here - advancing this South African debate beyond its present parameters.

In order to sketch this picture below, firstly, the noted conceptual extension from social capital to religious or spiritual capital will be traced. Secondly, the pertinent theological debate is to be outlined, both in its broader and its more specific dimensions. Lastly, the latter is recast by means of the social and religious or spiritual capital conceptual framework to indicate that an inaccurate characterisation of both the self and the other serves two matters poorly in (South) Africa: the tasks of Theology and - in actuality one of these tasks - of attending to the problems of social inequalities.

\section{Capital development}

The language of 'capital' has become a handy way to refer to what may activate human agents in order to reach certain desired outcomes within society. It is handy not only because such a term fits well within societies dominated by market economies and therefore the concept almost naturally 'rings true $^{\prime 6}$ but also because the metaphor (Urban 2003:354-389)

6. What is implicitly understood to be valid is seldom and for few people the result of rational reflection, deducing from basic ideas or principles what ought to be their beliefs, values, et cetera. For the most part, what is felt to be true or sensed to be valid is an unclear mirror of socially constructed and reinforced values. In the field of valid is an unclear mirror of socially constructed and reinforced values. In the field of
religion, this case has been made historically in one way, more or less sociologically, by Taylor (2007) and in another, more or less philosophically, by Deist (1994). 
of 'capital' is pliable enough to be employed in different, broadly related yet, on closer scrutiny, quite distinct ways. ${ }^{7}$ The association between society and faith has, of course, long been recognised: in the ancient world as intrinsically unified, in the modern world as at least conceptually distinct (see the famous historical analysis of Taylor 2007; cf. Berger \& Hefner 2003:1). However, this complementarity has not always been formulated in equally complimentary fashion (with the masters of this narrative including Feuerbach, Nietzsche, Marx, Durkheim, Freud, Weber and, currently, Berger, Casanova, Dawkins and others).

In a very useful recent overview paper on the concept of social capital, Gelderblom (2014) distinguishes between two ways in which this notion has broadly been used:

- as a description of supportive collaboration within society in order to achieve shared beneficial interests, with social capital then as the overarching inter-human or social resource, either bonding similar or bridging dissimilar agents together, as a human resource strategy towards communal ends (here, in analysing the work of Coleman 1988:95-120; Gambetta 1988:213-237; Gittell \& Vidal 1998; Putnam 2000 \& 1993; Uslaner 2009:127-142, 2004:501-507, 2001:569-590)

- as a description of one fairly circumscribed, yet nonisolated, aspect of society, namely along with financial, cultural and symbolic resources or forms of societal capital, a social networking dynamic that can be either to the advantage or the detriment of people, depending on the nature of power exertion on the part of agents with greater power in the particular social sphere concerned (here, drawing mainly on the work of Bourdieu 1985:723-744, 1986:241-258, 1991:117-126, 1998, 2005 and Bourdieu \& Wacquant 1992; cf. Verter 2003:150-174).

Bourdieu's more refined, narrowly specialised use of the concept of capital provides fertile ground for the formulation of further, more specifically focused permutations of the concept. Examples of these are - important for the work here - religious capital in referring to matters spiritual. ${ }^{8}$ However, given the nature of the terminology, here too (as Gelderblom [2014] points out with respect to social capital) the term is often employed in an overarching sense to refer to, for instance, any kind of influence religion can have on people (e.g. Middlebrooks \& Noghiu 2010:67-85) or any effect that religiously inclined people can have on society. A number of overviews of the concept of spiritual capital and its related designations, namely religious capital, ${ }^{9}$

7.This is characteristic of many foundational concepts across the....................... experienced as a malaise, such imprecision is, however, rather the strength of usefu ideas and their associated terminology: They 'travel' well enough to be suitable to varied contexts - similar to the nature of language. (Perhaps the often-expressed discomfort a such malleable conceptualature has something to do with the notion that definitions in the natural sciences would always be more settled and of firmer denotation.)

8.It should not be overlooked that, in the background here, lies the Weberian theory on the Calvinist origins of capitalism and his related concept of the Protestant work ethic (cf. Berger \& Hefner 2003:1).

9.These two most commonly encountered forms of the term - religious capital and spiritual capital - are at times used more or less synonymously. At other times, spirituality is seen as a more personal or a more deeply felt expression of religion whilst, at yet other times, it is seen as the opposite: the more over-arching concept. In Spirituality circles (for brief overviews of this relatively new discipline, see sacred capital (Urban 2003:354-389), faithful capital (Baker 2012:13) and religious social capital (Smidt 2004) - have been offered (in great depth: Palmer \& Wong 2013:4-16; cf. also e.g. Baker 2013:348; Berger \& Redding 2010:1-5; Guest 2007:184-195; Hämmerli 2011:196-203; Swart 2011:98-121; Jawad 2012:29-34; Montemaggi 2011:72-79; Wortham \& Wortham 2007:441-443). With the literature wavering between, broadly, an instrumentalist and an analytical use of the term (so too Palmer \& Wong 2013:5), spiritual capital is here, in this article, understood as follows:

- It indicates the (often unreflected) translation of a person's or persons' highest sensibilities of faith and deepest sensitivities of faith into expressions of action and inaction.

- These 'highest sensibilities' may refer to the divine or to creedal expressions (including negation - either as disavowal of the divine or as theology in the minor via negativa or mystic tradition) on the divine or to the noblest principles, religious or not. ${ }^{10}$

- The 'deepest sensitivities' indicates the (often unreflected-upon reflex) experience of the former.

- Such experience is always transformational in the sense that it gives existential meaning and personal or social depth (cf. Baker 2012:14-19), referring both to emotive-psychological senses of (well)being and to actions taken or declined.

- Although the dualism of the opening paragraph of this article is still intellectually recognisable here, the experience-and-expression (respectively internal and externalised) of spirituality goes beyond such dichotomies. ${ }^{11}$ Spirituality is thus integrative, ${ }^{12}$ with authenticity (cf. e.g. Flanagan 2012:2; O'Sullivan 2012: 43-47) as inherently part of the concept of spiritual capital. The latter is not meant as a value judgement or as a predetermined crusading point towards bettering society (cf. Berger \& Hefner 2003:4): Even where the results in action or non-action could be valued negatively in moral or other evaluations, the link between spiritual resources and experience-and-expression is not feigned. Something of this intangible quality can always be detected in people's awarenesses and engagements.

Given this understanding of spiritual capital, I move on to describing the matter that will be analysed according to these precepts of spiritual capital: the broader and specific dimensions of the Africanisation of the Bible or biblical interpretation debate in South Africa.

\footnotetext{
O'Sullivan 2012:50-55 and Kourie 2009:148-173; the most extensive contribution on this field is Waaijman 2000 and its various translations), though, these two terms are keenly distinguished, respectively to indicate the phenomenon of religiosity and the (individual and/or social) existentially-meaningful experience thereof (see e.g. Schneiders 2003:163-185)

10.The inter- or non-religious nature of spiritual capital (cf. Baker \& Miles-Watson 2008:442-464; Palmer \& Wong 2013:1-4) is one indication amongst a few that this concept finds its cultural expression within the currently unfolding 'phase' in Western(ised) societies of post-secularism (cf. Baker 2012:7-9; Lombaard 2014).

11.This, Urban (2003:357 cf. pp. 358-359) states, is fully in line with Bourdieu's 'intellectual agenda'.

12.Though not fully so: Humans make no perfect sense; hence I avoid invoking the in-vogue term 'holistic'.
} 


\section{Africanisation or contextualisation or relevance in South African Bible scholarship}

Part of the post-colonial African and anti-apartheid South African religious discourse since roughly the mid-1900s has been the insistence on the inculturation of Christianity within Africa. Put differently, it is the claim that Bible interpretation should come home in Africa. Whilst established churches have in time managed such inculturation quite remarkably via, for instance, liturgical symbols and languages (cf. e.g. Magesa 2004) and with many African Initiated Churches (cf. e.g. Ositelu 2002) doing so culturally to great effect (to the point that, to observers from other continents, the religious observance may often seem more like syncretism than contextualisation), it has been different in academic circles. This is unexpected since, if the whole of the South African academic Bible scholarship over the past half a century had to be painted with one broad stroke, it could generally speaking best be pictured against the backdrop of Liberation Theology. We are all liberation theologians. Moreover, all of South African biblical interpretation is hermeneutically, ideologically and sociologically extremely aware - though admittedly not in the senses in which, for instance, philosophers and sociologists would employ these terms.

The search for an African reading of the Bible has certainly been intense, crossing the boundaries of ecclesial and academic institutions, race and gender, age and more (with as some of the recent main works: ${ }^{13}$ Dube, Mbuvi \& Mbuwayesango 2012; De Wit \& West 2008; Holter 2007; Liew 2009; Page \& Bailey 2010; West \& Dube 2000). Classifying such readings is complex, with orientations stretching from Liberation Theology to Black Theology to African Theology (leaving aside for the moment the intersections of various feminisms with these approaches). However, all of these orientations have a shared strong emphasis on bringing (parts of) the Bible to bear on struggles that beset the African continent: political, developmental, medical, economic and other problems, even tragedies. This is attempted, generally, more by means of contextual-hermeneutical than by historical or textual-exegetical contributions, with the latter being the mainstay of First-World scholarship, on which (South) African contextual-hermeneutical Bible scholarship, nonetheless, draws strongly.

Let me, at this juncture, put my cards on the table regarding the quest for African readings of the Bible so as to avoid possible misunderstanding:

- I am in favour of this theological project - for reasons of personal piety (which is no longer the pietism of my youth), for intellectual reasons (there is no good reason why, for instance, Christianity's early Hellenistic

13.The same question that has been raised about writings on primary spiritualities (i.e. outside the mainstream of religion, such as Celtic spirituality) has to be asked about this branch of Theology too: Are self-critical questions from within these circles at all possible, or will research on these themes be only self-affirming? contextualisation through the choice of 25 December or later Germanic contextualisation by means of the Christmas tree should be privileged over current African, Asian and other contextualisation processes), for political reasons (the kind of liberalism I find myself attracted to) and, equally strongly, because of the protocols of my research specialism in Biblical Spirituality (cf. Lombaard 2012:111-137; Welzen 2011:37-60).

- I am however also critical of this theological project (Lombaard 2006:144-155, 2009:274-287, 2013:113-128), which evaluation may be summarised by the following formulation: The most prominent characteristic of the Africanisation project in Biblical Studies is the continuing call for the Africanisation of Biblical Studies. Rather than its compellingly confessed intended result of altering the litany of tragedies still befalling the African continent and its marginalised, biblical studies along these lines simply profess to doing so. ${ }^{14}$ The latter disposition, I argue, is intellectually dishonest: No study of a Bible text can directly alter any of the suffering on the continent. Additionally, no exegete has the training as a political scientist, development economist, social worker or some such background required for direct assistance to the marginalised. Such direct alleviation cannot be the intention of Bible scholarship: There is no straightforward link between understanding a biblical text anew and lessening misery. ${ }^{15}$ Such a linkage is more remote and may only be built by employing, for instance, theories of social and spiritual capital ${ }^{16}$ adapted to African social and religious constructions. The assumption that an unmediated or immediate connection between the ancient Bible text and current contexts exists is certainly a (dominant) part of broader African societies' many spiritualities. However, intellectuals should know better.

These two points summarise my position.

The problem with indicating the misconception (the problem indicated in the second bullet above) of current Africanisation or contextualisation or relevance theology is that it is reflexively equated with the rejection of this theological project itself. To illustrate this, I provide a personal example.

When at the 2005 Old Testament Society of South African congress at the University of KwaZulu-Natal in Pietermaritzburg I presented a paper (published as Lombaard

14.Such well-intentioned confession paired with poor execution has been a part of our religious heritage since antiquity (cf. Nel 2000:143-153).

15.I object too to defining Africa only in such negative terms. However, that is an argument to be made elsewhere.

16.In the background here lies the important distinction by Giddens (1984) concerning structure and agency in society: Structure is the way in which society is set up, which enables certain actions more than others. Agency, interactively, refers to the actions by people within a society set up in such a way, which on their part again shape the structure. What Bible scholarship can do is to alter the former, again shape the structure. What Bible scholarship can do is to alter the for
the structure of society, thus setting the idea-logical framework. From within this framework, for instance, students in following generations will express in their work (given further enabling circumstances) the commitments engendered during work (given further enabling circumstances) the commitments engendered during
their formation. For an example of how religious commitments can be applied in their formation. For an example of how religious commitments can be applie
such a way to the betterment of a problem in society, see O'Sullivan 2010. 
2006:144-155) making the above points, a rumour amongst those who did not attend my presentation immediately spread that 'I hear that you are against contextualisation'. This misrepresentation had seemingly not been corrected by either the 2006 publication of the 2005 paper or by its follow-up three years later (Lombaard 2009:274-287). The pleas for better Africanisation or contextualisation or relevance were simply taken as rejection of the same. The established involvement with the Africanisation project had become so strong that a proposal in solidarity for improvement came to be perceived as opposition to a heartfelt commitment.

In my 2005 paper (2006 article), reference was made to a publication of a very promising Old Testament scholar (Farisani 2004:24-55, with Farisani 2002 as the fuller background to this publication). I utilised his work as an example of commitment to certain aspects of contextualisation that seems to preclude finding other modern parallels which are comparatively speaking more fitting, analogically, with the historical situation reflected in the particular biblical text. Some ten years later, the compliment of referencing was returned in an inaugural lecture (Farisani 2013), ${ }^{17}$ presenting my position on these matters as, again, one of opposition to Africanisation or contextualisation or relevance.

Unbeknownst to the inaugurant, at the time, my most strongly worded critique (still in the mode of appraisal in solidarity) was in press (Lombaard 2013), in which precisely such misconstrual had been explicitly countered:

To pre-empt these [misrepresentations], the above criticism is not meant to imply that:

- the poor ought not to be cared for

- injustices in society should be left as is

- a bad past is being pined for

- theologians should strive to be context-free

- exegesis should not be brought into discussion with modern problems, and so forth.

The plea here is not for less but for more:

- The poor must be better cared for.

- Injustices should be eradicated more efficiently.

- The bad of the past (as with the bad in the present) should be mercilessly exposed.

- Theologians should be fully contextually aware.

- Exegesis should be a strong voice amongst many others in discussing modern problems, and so forth. (pp. 113-128)

Such commitments remain, and this contribution is part of giving expression to those sensibilities.

The prospect exists, though, that the continuing discussion will be characterised by yet more misunderstandings,

17.The present contribution is a direct but broad reaction to that inaugural lecture Once the latter has been published, a detailed step-by-step reaction may follow, Once the latter has been published, a detailed step-by-step reaction may follow,
as requested by colleague Madipoane Masenya at the annual meeting of the Old as requested by colleague Madipoane Masenya at the annual meeting
Testament Society of South Africa in Johannesburg in September 2014. reciprocated, and misrepresentations, inadvertent. Such a debate may end with nothing resolved and with the issues at stake merely being tabled - perhaps more openly than usual but with no true advance. Therefore, I provide this attempt, by means of the concept of spiritual capital, to sketch my position differently. The aim is not to retract my views but to state them otherwise in the hope that they will be better understood. Once my position is conveyed in this alternate way, one can hope that the project of Africanisation or contextualisation or relevance in South African Bible scholarship can progress with greater efficacy, that is, with greater intellectual integrity when measured against the interdisciplinary protocols of our time.

\section{The ebony tower}

In his influential book on religious communication, Kraft (1999:103-104) points out as a misconception the pious sentiment amongst many engaged in evangelisation and mission that ' $(\mathrm{t})$ he Holy Spirit will make up for all mistakes if we are sincere, spiritual and prayerful enough' (Kraft 1999:103). This much, mission history, as much as current mission practice, show us too. A parallel misconception seems, however, to go along with the Africanisation or contextualisation or relevance trajectory in South African Bible scholarship, as summarised above. Rather, I propose, Bible scholarship has much to learn from the Social Sciences or Humanities such as Sociology (Felter 2012:80-97) and Journalism (Lombaard 1999:22-46), namely as fully complementary and critically interacting disciplines. This is even more valid of the post-secular time in which we find ourselves in which boundaries between 'the religious' and 'the secular' are avowedly indistinguishable..$^{18}$

However, setting up such canons of scholarship as standard practice requires critical thinking on all fronts: now, as much without unreflected assumptions about the apparent current expectations on the spontaneous efficacy of research, as of long accepted in South African Bible scholarship - the subject matter of one's research and the methodologies involved. Put differently, although academic theologians may have broken through the first naiveté (Ricoeur 1967:350-352) as far as many religious fundamentals (e.g. the concepts of God, the Bible, church, revelation, etc.) or 'vertical matters' are concerned, I have argued above that this is not equally the case with 'horizontal matters'. It seems still to be the case that the implicit current rationale at times corresponds in some ways to that of popular sermonising: Once the message has been delivered (the paper read, the book published, etc.) on a topic of serious societal concern, it is often simply assumed that, therefore, the theology is relevant - the good work has been done. This may seem virtuous, and indeed, this itself is idealistic, in a - vide supra - Platonic sense of the term. However, the way in which research affects society, the role of the university within its communities, the manners in which faith impulses transform society, and all the intermediary

18.Guest (2007:181) follows Beckford (1989:170) and Lyon (2000) in arguing that this has much to do with a shift within religion and is not only the result of shifts in societal sensitivities towards matters of faith. 
societal layers and processes - all have remained largely unconsidered.

In coming to terms with these Aristotelian dimensions of the South African biblical-theological enterprise, that is, its contextualisation or its reality, concepts such as spiritual capital prove greatly helpful in indicating that this horizontal first naiveté has yet to be broken through. There is no direct, automatic connection between publishing research and altering society. ${ }^{19}$ To assume that the research would be more significant because it is, emotively, thematically relevant for Africa and to insist on such self-efficacy when publishing research on (for instance) Africa amount to all the old clichés: confessional armchair theology, practiced in the ebony tower. The research may be well intended. Still, to be intellectually honest with ourselves, it goes nowhere by itself. There is no deus ex machina process by means of which Bible analyses automatically solve societal problems as would a mechanical arm in a staged play in ancient Greece. A more realistic, contextually sensitive view of the relationship between research and society is required.

What is more, the concept of spiritual capital has inherent to it the (typical post-secular - Lombaard 2014) acknowledgement that a sense of the divine amongst human agents has the potential to influence society differently, precisely because it brings about sensitivities and activities to improve the circumstances of those in dire need. The either-or choice between vertical theology and horizontal theology disappears. ${ }^{20}$ Thus, the characterisation as the one or the other of critics who point out insufficiencies becomes meaningless. The tasks of Theology, pressingly also those related to social inequalities are better served by us being greater realist theologians.

\section{Acknowledgements}

\section{Competing interests}

The author declares that he has no financial or personal relationships which may have inappropriately influenced him in writing this article.

\section{References}

Baker, C., 2012, 'Exploring spiritual capital: Resources for an uncertain future?', in M. O'Sullivan \& B. Flanagan (eds.), Spiritual capital: Spirituality in practice in Christian perspective, pp. 7-22, Ashgate, Farnham.

Baker, C., 2013, 'Moral freighting and civic engagement: A UK perspective on Putnam and Campbell's theory of religious-based social action', Sociology of Religion 74(3), 343-369. http://dx.doi.org/10.1093/socrel/srt013

Baker, C. \& Miles-Watson, J., 2008, 'Exploring secular spiritual capital: An engagement in religious and secular dialogue for a common future', International Journal of Public Theology 2(4), 442-464. http://dx.doi.org/10.1163/156973208X335297

Beckford, J.A., 1989, Religion and advanced industrial society, Unwin Hyman, London.

Berger, P. \& Redding, G., 2010, 'Introduction: Spiritual, social, human, and financial capital', in P. Berger \& G. Redding (eds.), The hidden form of capital: Spiritual influences in societal progress, pp. 1-13, Anthem Press, London.

Berger, P.L. \& Hefner, R.W., 2003, 'Spiritual capital in comparative perspective', paper presented at the Spiritual Capital Planning Meeting, 10-11 October 2003, viewed 11 February 2015, from http://metanexus.org/archive/ spiritualcapitalresearchprogram/pdf/Berger.pdf

19.The reflex belief is always: bettering society.

20.This is entirely in the nature of spirituality too - cf. for example, Flanagan (2012:3).
Bourdieu, P., 1985, 'The social space and the genesis of groups', Theory and Society 14(6), 723-744. http://dx.doi.org/10.1007/BF00174048

Bourdieu, P., 1986, 'The forms of capital', in J.E. Richardson (ed.), Handbook of theory and research for the sociology of education, pp. 241-258, Greenwood, New York.

Bourdieu, P., 1991, 'Rites of institution', in P. Bourdieu (ed.), Language and symbolic power, pp. 117-126, Polity Press, Cambridge.

Bourdieu, P., 1998, Practical reason, Polity Press, Cambridge.

Bourdieu, P., 2005, The social structures of the economy, Polity Press, Cambridge.

Bourdieu, P. \& Wacquant, L.J.D., 1992, An invitation to reflexive sociology, Polity Press, Cambridge.

Caputo, J., 2006, Philosophy and theology, Abingdon Press, Nashville.

Coleman, J.S., 1988, 'Social capital in the creation of human capital', American Journal of Sociology 94, 95-120. http://dx.doi.org/10.1086/228943

Deist, F.E., 1994, Ervaring, rede en metode in Skrifuitleg: 'n Wetenskapshistoriese ondersoek na Skrifuitleg in die Ned. Geref. Kerk, 1840-1990, Raad vir Geesteswetenskaplike Navorsing, Pretoria.

De Wit, H. \& West, G.O., 2008, African and European readers of the Bible in dialogue: In quest of a shared meaning, Brill, Leiden.

Dube, M.W., Mbuvi, A.M. \& Mbuwayesango, D.R. (eds.), 2012, Postcolonial perspectives in African biblical interpretations, Society of Biblical Literature, Atlanta.

Farisani, E.B., 2002, 'The use of Ezra-Nehemiah in a quest for a theology of renewal, transformation and reconstruction', PhD thesis, School of Theology, University of Natal, Pietermaritzburg.

Farisani, E.B., 2004, 'Ethnicity in Ezra-Nehemiah', Theologia Viatorum 28(1), 24-55.

Farisani, E.B., 2013, 'Dispelling myths about African biblical hermeneutics: The role of current trends in African biblical hermeneutics in the post-apartheid South Africa', inaugural lecture, 03 September, University of South Africa.

Felter, K.D., 2012, 'Breaking with illusion: The sociology of Pierre Bourdieu as a challenge to theology', Studia Theologica 66, 80-97. http://dx.doi.org/10.1080/ 0039338X.2012.674974

Flanagan, B., 2012, 'Introduction', in M. O'Sullivan \& B. Flanagan (eds.), Spiritual capital: Spirituality in practice in Christian perspective, pp. 1-5, Ashgate, Farnham

Gambetta, D., 1988, 'Can we trust trust?', in D. Gambetta (ed.), Trust: Making and braking cooperative relations, pp. 213-237, Blackwell, New York.

Gelderblom, D., 2014, 'The landscape of social capital: Bridging the micro-macro gap', paper presented at the conference of the South African Sociological Association, Nelson Mandela Metropolitan University, Port Elizabeth, South Africa, 06-09 July.

Giddens, A., 1984, The constitution of society: Outline of the theory of structuration, Polity Press, Cambridge.

Gittell, R. \& Vidal, A., 1998, Community organizing: Building social capital as a development strategy, Sage, London.

Guest, M.J., 2007, 'In search of spiritual capital: The spiritual as a cultural resource', in K. Flanagan \& P.C. Jupp (eds.), The sociology of spirituality, pp. 181-200, Ashgate, Aldershot.

Hämmerli, M., 2011, 'Religion and spirituality between capital and gift', Religion \& Theology 18, 195-210. http://dx.doi.org/10.1163/157430111X613728

Holter, K. (ed.), 2007, Interpreting classical religious texts in contemporary Africa, Acton Publishers, Nairobi.

Jawad, R., 2012, 'A secular response to social solidarity?: Social capital, religion and the implications for social policy', in M. O'Sullivan \& B. Flanagan (eds.), Spiritual capital: Spirituality in practice in Christian perspective, pp. 23-41, Ashgate, Farnham.

Kourie, C., 2009, 'Spirituality and the university', Verbum et Ecclesia 30(1), 148-173. http://dx.doi.org/10.4102/ve.v30i1.67

Kraft, C.H., 1999, Communication Jesus' way, rev. edn., William Carey Library, Pasadena.

Liew, T.B. (ed.), 2009, Postcolonial interventions, Sheffield Phoenix Press, Sheffield.

Lombaard, C., 1999, 'Kontekstuele prediking met behulp van kommentaarjoernalistiek', in C. Lombaard (ed.), '... in die wêreld ...': Vyf bydraes tot kontekstuele prediking, pp. 22-46, Departement Latyn en Grtieks, Randse Afrikaanse Universiteit, pp. $22-46$,
Johannesburg.

Lombaard, C., 2006, 'The relevance of Old Testament science in/for Africa: Two false pieties and focussed scholarship', Old Testament Essays 19(1), 144-155.

Lombaard, C., 2009, 'Does contextual exegesis require an affirming Bible?: Lessons from "apartheid" and "Africa" as narcissistic hermeneutical keys', Scriptura 101, 274-287. http://dx.doi.org/10.7833/101-0-639

Lombaard, C., 2012, The Old Testament and Christian Spirituality: Theoretical and practical essays from a South African perspective, Society of Biblical Literature, practical

Lombaard, C., 2013, 'Faith matters: Two aspects of the present theological scene in South Africa', Studia Historiae Ecclesiasticae XXXIX, special supplement for Cornel du Toit, 113-128.

Lombaard, C., 2014, “'And never the twain shall meet?": Post-secularism as newly unfolding religio-cultural phase and wisdom as ancient Israelite phenomenon: Spiritualities and implications compared and contrasted', paper presented at the 4th Global Conference: Spirituality in the 21st Century; Prague, 18-20 March. 4th Global Conference: Spirituality in the 21st Century; Prague, 18-20
Publication forthcoming: Journal of Theology for Southern Africa, 2015. 
Lyon, D., 2000, Jesus in Disneyland: Religion in postmodern times, Polity Press, Cambridge.

Magesa, L., 2004, Anatomy of inculturation: Transforming the church in Africa, Orbis Books, New York.

Middlebrooks, A. \& Noghiu, A., 2010, 'Leadership and spiritual capital: Exploring the link between individual service disposition and organizational value', International Journal of Leadership Studies 6(1), 67-85.

Montemaggi, F.E.S., 2011, 'The enchanting dream of "spiritual capital", Implicit Religion 14(1), 67-86. http://dx.doi.org/10.1558/imre.v14i1.67

Nel, P.J., 2000, 'Social justice as religious responsibility in Near Eastern religions: Historic ideal and ideological illusion', Journal of Northwest Semitic Languages 26(2), 143-153.

Ositelu, R.O.O., 2002, African instituted churches: Diversities, growth, gifts, spirituality and ecumenical understanding of African Initiated Churches, Lit Verlag, Münster.

O'Sullivan, M., 2010, How Roman Catholic theology can transform male violence against women: Explaining the role of religion in shaping cultural assumptions about gender, Edwin Mellen Press, New York.

O'Sullivan, M., 2012, 'Spiritual capital and the turn to spirituality', in M. O'Sullivan \& B. Flanagan (eds.), Spiritual capital: Spirituality in practice in Christian perspective, pp. 43-59, Ashgate, Farnham.

Page, H.R. \& Bailey, R.C., 2010, The Africana Bible: Reading Israel's scriptures from Africa and the African diaspora, Fortress Press, Minneapolis.

Palmer, D.A. \& Wong, M., 2013, 'Clarifying the concept of spiritual capital', pape prepared for the Conference on the Social Scientific Study of Religion, Chines University of Hong Kong, 10-13 July, viewed 11 February 2015, from http://foss. hku.hk/ExCEL3/wp-content/uploads/2014/05/Concept-of-Spiritual-Capital.pdf

Putnam, R.D., 1993, Making democracy work: Civic traditions in modern Italy, Princeton University Press, Princeton.

Putnam, R.D., 2000, Bowling alone: The collapse and revival of American community, Simon and Schuster, New York.

Ricoeur, P., 1967, The symbolism of evil, Beacon Press, Boston
Schneiders, S., 2003, 'Religion vs spirituality: A contemporary conundrum', Spiritus 3(2), 163-185. http://dx.doi.org/10.1353/scs.2003.0040

Smidt, C.E. (ed.), 2004, Religion as social capital: Producing the common good, Baylor University Press, Waco.

Swart, I., 2011, 'Religion and social capital research in South Africa: Mapping an agenda in progress', in T. Hjelm (ed.), Religion and social problems, pp. 98-121, Routledge, New York.

Taylor, C., 2007, A secular age, Belknap Press of Harvard University Press, Cambridge.

Urban, H.B., 2003, 'Sacred capital: Pierre Bourdieu and the study of religion', Method \& Theory in the Study of Religion 15, 354-389. http://dx.doi. org/10.1163/157006803322697416

Uslaner, E., 2001, 'Producing and consuming trust', Political Science Quarterly 115(4), 569-590. http://dx.doi.org/10.2307/2657610

Uslaner, E., 2004, 'Trust and social bonds: Faith in others and policy outcomes reconsidered', Political Research Quarterly 57(3), 501-507. http://dx.doi. org/10.1177/106591290405700314

Uslaner, E., 2009, 'Corruption', in G.T. Svendsen \& G.L.H. Svendsen (eds.), Handbook of social capital: The troika of sociology, political science and economics, pp. 127142, Edward Elgar, London. http://dx.doi.org/10.4337/9781848447486.00016

Verter, B., 2003, 'Spiritual capital: Theorizing religion with Bourdieu against Bourdieu', Sociological Theory 21, 150-174. http://dx.doi.org/10.1111/1467-9558.00182

Waaijman, K., 2000, Spiritualiteit: Vormen, grondslagen, patronen, Carmelitana, Gent.

Welzen, H., 2011, 'Contours of Biblical Spirituality as a discipline', in P.G.R. De Villiers \& L.K. Pietersen (eds.), The Spirit that inspire: Perspectives on Biblical spirituality, Acta Theologica Supplementum 15, pp. 37-60, University of the Free State Press, Bloemfontein.

West, G.O. \& Dube, M.W. (eds.), 2000, The Bible in Africa: Transactions, trajectories, and trends, Brill, Boston.

Wortham, R.A. \& Wortham, C.B., 2007, 'Spiritual capital and the "good life"', Sociological Spectrum 27, 439-452. http://dx.doi.org/10.1080/02732170701335053 